\title{
ERRATUM
}

\section{The influence of dietary fatty acids on liver fat content and metabolism - ERRATUM}

\author{
Leanne Hodson, Fredrik Rosqvist and Siôn A Parry
}

doi: 10.1017/S0029665119000569, Published online by Cambridge University Press 3 April 2019.

The above article was published with the incorrect conference title.

\section{Original Text (page 1)}

The Nutrition Society Summer Meeting was held at the University of Leeds, UK on 10-12 July 2018

Conference on 'Getting energy balance right'

Symposium 3: Dietary factors in energy metabolism

\section{Correction}

The Nutrition Society Winter Meeting was held at the Royal Society of Medicine, London, 4-5 December 2018

Conference on 'Optimal diet and lifestyle strategies for the management of cardio-metabolic risk'

Symposium 2: Impact of dietary fatty acids on key metabolic tissues (fat depots and muscle)

\section{Reference}

Hodson L, Rosqvist F \& Parry SA (2019) The influence of dietary fatty acids on liver fat content and metabolism. Proceedings of the Nutrition Society, 1-12. doi:10.1017/S0029665119000569 